\title{
MORFOLOŠKA I FENOLOŠKA VARIJABILNOST OBIČNE BUKVE (FAGUS SYLVATICA L.) U MEĐUNARODNOM TESTU PROVENIJENCIJA U BOSNI I HERCEGOVINI
}

\author{
MORPHOLOGICAL AND PHENOLOGICAL VARIABILITY \\ OF COMMON BEECH (Fagus sylvatica L.) IN THE INTERNATIONAL \\ PROVENANCE TEST IN BOSNIA AND HERZEGOVINA
}

Mirzeta MEMIŠEVIĆ HODŽIĆ ${ }^{1}$, Dalibor BALLIAN ${ }^{1,2}$

\section{SAŽETAK}

Cilj istraživanja je usporediti rast provenijencija obične bukve, te utvrditi početak i završetak fenoloških faza listanja provenijencija obične bukve u međunarodnom testu provenijencija u Bosni i Hercegovini.

Test obuhvaća osam provenijencija iz Bosne i Hercegovine, četiri iz Njemačke, tri iz Srbije, po dvije iz Hrvatske, Rumunije i Švicarske te jednu iz Mađarske (tablica 1).

U proljeće 2017. godine mjerili smo visine i promjere vrata korijena biljaka u međunarodnom testu provenijencija. Također smo promatrali i bilježili pojavu fenoloških faza listanja kroz šest faza (slika 1): A - Spavajući pup; B - Pupovi izduženi, nabubreni, žućkasto-zelenkaste boje; C - Pupovi se počinju otvarati i vidi se prvo zelenilo; D - Počinju se javljati savijeni dlakavi listići; E - Listovi su odmotani, još lepezasti, prisutne blijede liske; F - Listovi su potpuno razvijeni, glatki i široki.

Prosječna visina za sve provenijencije bila je $164,6 \mathrm{~cm}$ (tablica 2), a prosječan promjer vrata korjena $33,4 \mathrm{~mm}$ (tablica 5). Najmanju prosječnu visinu $(104,2 \mathrm{~cm})$ i promjer $(22,6 \mathrm{~mm})$ imala je provenijencija Alba - Iulia iz Rumunije (9664). Najveću prosječnu visinu $(197,4 \mathrm{~cm})$ i promjer $(40,1 \mathrm{~mm})$ imala je provenijencija Dilj Čaglinski iz Hrvatske (9624).

Utvrdili smo razlike između provenijencija u pogledu pojavljivanja fenoloških faza listanja (tablica 8), kao i dužini trajanja faza (tablica 10). Faza B se najranije pojavila 31.3. kod provenijencija Grmeč Jasenica i Dinara iz Bosne i Hercegovine i Cer iz Srbije. Najkasnije se pojavila 8.5. kod provenijencija Herzogenbuchsee iz Švicarske i NS Hasbruch iz Njemačke. Fenofaza F najranije se pojavila 1.5. kod provenijencije Valkonya iz Mađarske. Analiza varijanse pokazala je da postoje statistički značajne razlike između provenijencija, kako u visini (tablica 3) i promjeru vrata korijena (tablica 6) tako i u dužini trajanja fenoloških faza (tablica 10).

Biljke u međunarodnom testu provenijencija obične bukve su za vrijeme mjerenja bile stare 12 i 13 godina. Potrebno je vršiti daljnja mjerenja morfoloških svojstava kako bi se utvrdile tendencije rasta pojedinih provenijencija u idućim fazama razvoja. Također je potrebno promatrati fenološke faze kako bi se procijenili utjecaji genetske konstitucije i godišnje klime na fenološka kretanja. Rezultati ovog istraživanja poslužit će za odabir najboljih provenijencija po produktivnosti i otpornosti na kasne proljetne mrazeve.

KLJUČNE RIJEČI: fenološke faze listanja, visina, promjer vrata korijena, obična bukva, test provenijencija

1 Dr. sc. Mirzeta Memiševuć Hodžić, Viši asistent, Prof. dr. sc. Dalibor Ballian, balliandalibor9@gmail.com, Univerzitet u Sarajevu, Šumarski fakultet

${ }_{2}^{2}$ Prof. dr. sc. Dalibor Ballian, Gozdarski institut Slovenije, Ljubljana 


\section{UVOD}

\section{INTRODUCTION}

Obična bukva (Fagus sylvatica L.) je jedna je od najznačajnih gospodarskih vrsta u Bosni i Hercegovini. Iako je obična bukva morfološki manje varijabilna vrsta, istraživanja provenijencija u različitim dijelovima areala upućuju na njezinu značajnu unutarpopulacijsku i međupopulacijsku varijabilnost (Kajba 2003; Ballian i sur. 2019).

Obična bukva jedina je vrsta šumskog drveća u Europi koja od prirode raste u širokom rasponu nadmorskih visina (od $100 \mathrm{~m}$ pa sve do $2000 \mathrm{~m}$ n.v.) i to na različitim supstratima. Za uspješan rast traži submontano - montanu vlažnu klimu s najmanje $600-700 \mathrm{~mm}$ godišnjih padalina, a pokazuje i dobru adaptabilnost prema različitim ekološko-klimatskim uvjetima (Pintarić 2002; Ballian i sur. 2019).

Istočna granica rasprostranjenosti određena je zračnom vlagom i pojavom kasnog mraza (Pukacki 1990), a prilagođena je umjerenoj i vlažnoj oceanskoj klimi. Iako je relativno otporna na niske temperature, osjetljiva je na kasni proljetni mraz, što predstavlja ograničavajući čimbenik na nižim područjima.

Prvi pokus s provenijencijama obične bukve osnovan je 1877. godine u Botaničkom vrtu u Njemačkoj (Kienitz 1879), a nešto kasnije se takvi pokusi osnivaju u Belgiji, Danskoj, Francuskoj i nekim drugim europskim zemljama (Vidaković i Krstinić 1985).

Morfološku varijabilnost obične bukve u međunarodnom testu provenijencija kod Kaknja istraživali su Ballian i Zukić (2011) i Ballian i Jukić (2014/2015) i utvrdili analizom varijanse statistički visoko značajne razlike u svojstvu promjera na vratu korijena i visinama biljaka, koje su potvrđene Duncanovim testom.

U brojnim suvremenim pokusima s običnom bukvom provođena su višegodišnja fenološka istraživanja (Muhs 1985). Rezultati su pokazali da provenijencije iz istočnog i sjeveroistočnog dijela areala, kao i provenijencije s viših nadmorskih visina zahtijevaju manju temperaturnu sumu za izlistavanje te stoga i ranije listaju.

Dobiveni rezultati upućuju na važnost fenologije pri procjeni sposobnosti prilagođavanja bukovih sastojina na određene ekološke uvjete. Istraživanjem 159 provenijencija obične bukve dobivene su značajne unutarpopulacijske i međupopulacijske razlike fenološke varijabilnosti (von Wüehlisch i sur. 1995). Istraživanja 15 europskih provenijencija obične bukve iz osam zemalja, proveli su Liesebach i sur. (1999), a rezultati su također utvrdili značajnu međupopulacijsku i unutarpopulacijsku varijabilnost fenoloških svojstava.

Cilj ovoga istraživanja bio je usporediti rast provenijencija obične bukve u međunarodnom testu provenijencija koji obuhvaća osam provenijencija iz Bosne i Hercegovine, četiri iz Njemačke, tri iz Srbije, po dvije iz Hrvatske, Rumunije i Švicarske, te jednu iz Mađarske, kao i utvrditi postojanje razlika u datumima početaka i završetaka fenoloških faza listanja između istraživanih provenijencija, što bi bilo važno za buduće gospodarenje i obnovu bukovih šuma uz povećanje proizvodnosti i adaptabilnosti.

\section{MATERIJAL I METODE MATERIAL AND METHODS}

Istraživanja su provedena na 22 provenijencije obične bukve u međunarodnom testu provenijencija, od kojih osam potječe iz Bosne i Hercegovine, četiri iz Njemačke, tri iz Srbije, a po dvije iz Hrvatske, Rumunije i Švicarske te jedna iz Mađarske (tablica 1).

U proljeće 2017. godine (biljke starosti 12 i 13 godina) mjerena su morfološka svojstva visina $(\mathrm{cm})$ uz pomoć štapnog metra, te promjer vrata korijena biljaka $(\mathrm{mm})$ elektronskim pomičnim mjerilom. Mjerene su sve biljke u testu provenijencija, a broj biljaka prikazan je u tablici 2. Podaci su obrađeni statističkim programom SPSS 20.0 i izračunati osnovni deskriptivni pokazatelji. Urađena je i analiza varijanse i Duncanov multipli test.

Fenološka opažanja obavljana su vizualno i to na sljedećim datumima: 10.3.,15.3., 26.3., 31.3., 4.4., 10.04., 24.04., 01.05., 08.05., 15.05., 20.5. 2017. godine i to na svim biljkama tijekom istoga dana.

Listanje biljaka istraživanih provenijencija pratilo se u šest karakterističnih fenofaza (Forstreuter 2002), od spavajućeg (zimskog) pupa do potpuno razvijenog lista:

A - Spavajući (zimski) pup (smeđe do tamnosmeđe boje);

B - Pupovi bubre (izduženi, nabubreni, žućkasto-zelenkaste boje, imaju opnu koju vršci iglica još nisu probili);

C - Pupovi se počinju otvarati (napukli) i vidi se prvo zelenilo;

D - Počinju se javljati savijeni (smotani) dlakavi listići;

E - Listovi su odmotani, još lepezasti, prisutne blijede liske;

F - Listovi su potpuno razvijeni, glatki i široki.

Posmatrane fenofaze prikazane su na slici 1.

Na osnovi prikupljenih podataka definiran je početak i završetak pojedinih fenoloških faza po provenijencijama. Korištenjem SPSS programa izračunata je prosječna dužina trajanja faza po provenijencijama, te napravljena analiza varijanse za dužinu trajanja faza po provenijencijama.

Međunarodni test provenijencija obične bukve osnovan je u proljeće 2007. godine u odjelu 41 koji pripada gospodarskoj jedinici „Donja Trstionica - Goruša“ (ŠPP „Kakanjsko"). Nalazi se na 510 do 568 metara nadmorske visine u slivnom području Lužničkog potoka (koordinate 

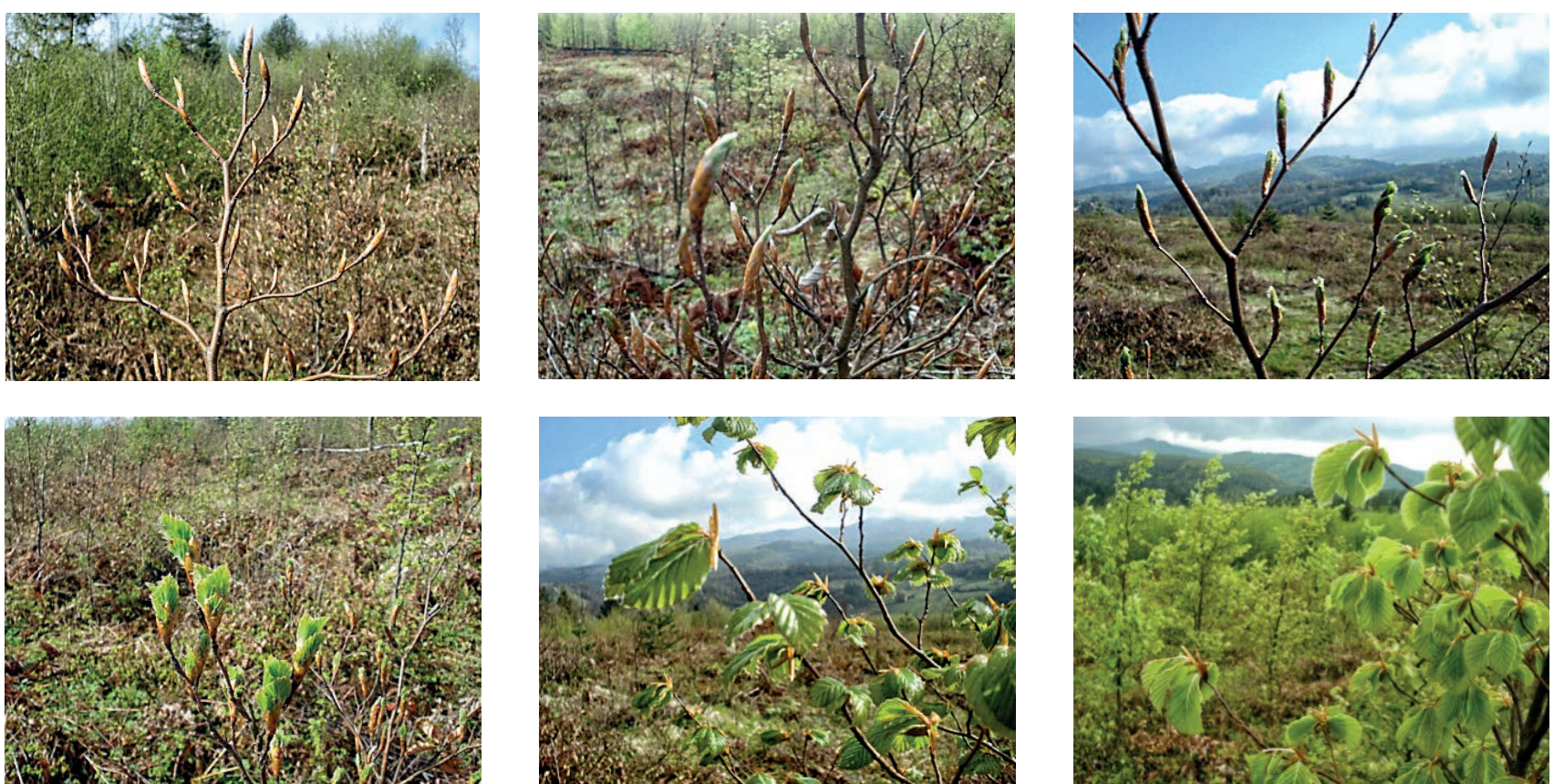

Slika 1. Fenofaze listanja obične bukve

Figure 1. Phenological stages of leafing of common beech

$\left.44^{\circ} 04^{\prime} 15^{\prime \prime} \mathrm{N} 18^{\circ} 11^{\prime} 32^{\prime \prime} \mathrm{E}\right)$, koji je desna pritoka rijeke Goruše (desna pritoka rijeke Bosne). Teren širog područja oko ovog odjela je blago nagnut i zaravnjen, s prosječnim nagibom terena oko 7\%. Ekspozicija je uglavnom sjeveroistočna. Od zemljišta javljaju se kompleks rendzine i kiselog smeđeg zemljišta; - kompleks kiselog smeđeg i ilimerizovanog zemljišta i smeđe zemljište (na manjem dijelu površine). Odjel graniči s privatnim posjedima i okolnim seoskim naseljima, čije je stanovništvo zadovoljavaći potrebe za ogrijevom te ispašom za stoku, sastojine ovog $i$ susjednog odjelja degradiralo ili pretvorilo u izdanačke šume s vrlo malo kvalitetne drvne mase u zalihi sastojina.
Odjel je pod utjecajem umjereno kontinentalne klime, koju karakteriziraju hladne zime i umjereno topla ljeta s velikim količinama padalina.

Sadnice su bile starosti $2+0$ i $3+0$ godina kada su posađene. Razmak između biljaka je $2 \times 1 \mathrm{~m}$ sa 50 biljaka po plohi. Sadnice su posađene u randomiziranom blok dizajnu, 20 provenijencija u tri ponavljanja i dvije provenijencije sa po jednim ponavljanjem (provenijencije Konjuh i Avala). Provenijencija Wildbad imala je samo 20 biljaka i nadopunjena je s provenijencijom Alesd koja ima 30 biljaka. Ukupno je u testu provenijencija posađeno 3100 sadnica.

$\begin{array}{cccccccccc} & 9624 & 9625 & 9630 & 9631 & 9632 & 9633 & 9642 \\ \text { Blok 1 } & 9643 & 9646 & 9647 & 9648 & 9649 & 9659 & 9660 \\ & 9661 & 9662 & 9663 & 9664 & 9665 & 9668 & 9669 \\ \text { Blok 2 } & 9632 & 9633 & 9642 & 9643 & 9646 & 9647 & 9663 & 9664 \\ & 9649 & 9659 & 9660 & 9661 & 9662 & 9625 & 9630 \\ \text { Blok 3 } & 9665 & 9666 & 9668 & 9669 & 9624 & & & \\ & 9663 / 9646 & 9647 & 9648 & 9649 & 9659 & 9660 & 9661 \\ & 9662 & 9663 & 9664 & 9665 & 9665 & 9669 & 9643\end{array}$

Shema sadnje provenijencija u tekstu

Planting scheme of provenances in the test 
Tablica 1. Istraživane provenijencije

Table 1. Researched provenances

\begin{tabular}{|c|c|c|c|c|c|c|}
\hline $\begin{array}{l}\text { Broj } \\
\text { No }\end{array}$ & $\begin{array}{l}\text { Oznaka provenijencije } \\
\text { Provenance label }\end{array}$ & $\begin{array}{l}\text { Naziv provenijencije } \\
\text { Provenance name }\end{array}$ & $\begin{array}{l}\text { Starost sadnica } \\
\text { Age of seedlings }\end{array}$ & $\begin{array}{c}\text { Sjeverna } \\
\text { geografska širina } \\
\text { Latitude }\end{array}$ & $\begin{array}{c}\text { Istočna } \\
\text { geografska dužina } \\
\text { Longitude }\end{array}$ & $\begin{array}{c}\text { Nadmorska visina } \\
\text { Altitude }\end{array}$ \\
\hline 1 & B\&H - 9630 & Tajan, Zavidovići & $3+0$ & $44^{\circ} 23^{\prime}$ & $18^{\circ} 03^{\prime}$ & 700 \\
\hline 2 & B\&H - 9631 & Konjuh, Kladanj & $3+0$ & $44^{\circ} 16^{\prime}$ & $18^{\circ} 34^{\prime}$ & 840 \\
\hline 3 & B\&H - 9632 & Tešanj Crni Vrh I & $3+0$ & $44^{\circ} 33^{\prime}$ & $17^{\circ} 59^{\prime}$ & 500 \\
\hline 4 & B\&H - 9633 & Grmeč Jasenica & $3+0$ & $44^{\circ} 16^{\prime}$ & $16^{\circ} 18^{\prime}$ & 450 \\
\hline 5 & B\&H - 9659 & Bugojno Vranica Bistrica & $2+0$ & $43^{\circ} 33^{\prime}$ & $17^{\circ} 49^{\prime}$ & 750 \\
\hline 6 & B\&H - 9660 & Tešanj Crni Vrh II & $2+0$ & $44^{\circ} 33^{\prime}$ & $17^{\circ} 59^{\prime}$ & 500 \\
\hline 7 & B\&H - 9661 & Bosanska Krupa Bastra Ćorkovača & $2+0$ & $44^{\circ} 45^{\prime}$ & $16^{\circ} 14^{\prime}$ & 720 \\
\hline 8 & B\&H- 9662 & Dinara & $2+0$ & $44^{\circ} 06^{\prime}$ & $16^{\circ} 30^{\prime}$ & 950 \\
\hline 9 & $\mathrm{CH}-9643$ & Herzogenbuchsee & $3+0$ & $47^{\circ} 11^{\prime}$ & $07^{\circ} 40^{\prime}$ & 500 \\
\hline 10 & $\mathrm{CH}-9665$ & Sihlwald & $2+0$ & $47^{\circ} 12^{\prime}$ & $07^{\circ} 21^{\prime}$ & 1050 \\
\hline 11 & CRO - 9624 & Dilj Čaglinski & $3+0$ & $45^{\circ} 17^{\prime}$ & $18^{\circ} 01^{\prime}$ & 350 \\
\hline 12 & CRO - 9625 & Vrani Kamen & $3+0$ & $45^{\circ} 37^{\prime}$ & $17^{\circ} 19^{\prime}$ & 600 \\
\hline 13 & GER - 9646 & BW Wildbad & $3+0$ & $48^{\circ} 46^{\prime}$ & $08^{\circ} 35^{\prime}$ & 700 \\
\hline 14 & GER - 9647 & BW Schwäb. Alb & $3+0$ & $48^{\circ} 00^{\prime}$ & $10^{\circ} 00^{\prime}$ & 650 \\
\hline 15 & GER - 9648 & BY Höllerbach & $3+0$ & $49^{\circ} 01^{\prime}$ & $13^{\circ} 14^{\prime}$ & 755 \\
\hline 16 & GER - 9649 & NS Hasbruch & $3+0$ & $53^{\circ} 08^{\prime}$ & $08^{\circ} 26^{\prime}$ & 35 \\
\hline 17 & HUN - 9642 & Valkonya & $3+0$ & $46^{\circ} 30^{\prime}$ & $16^{\circ} 45^{\prime}$ & 300 \\
\hline 18 & RO - 9664 & Alba lulia & $2+0$ & $46^{\circ} 10^{\prime}$ & $23^{\circ} 05^{\prime}$ & 860 \\
\hline 19 & RO - 9663 & Alesd & $2+0$ & $46^{\circ} 10^{\prime}$ & $22^{\circ} 15^{\prime}$ & 490 \\
\hline 20 & SRB - 9666 & Avala & $2+0$ & $44^{\circ} 12^{\prime}$ & $20^{\circ} 45^{\prime}$ & 745 \\
\hline 21 & SRB - 9668 & Fruška Gora & $2+0$ & $45^{\circ} 10^{\prime}$ & $19^{\circ} 47^{\prime}$ & 360 \\
\hline 22 & SRB - 9669 & Cer & $2+0$ & $44^{\circ} 12^{\prime}$ & $19^{\circ} 50^{\prime}$ & 745 \\
\hline
\end{tabular}

CRO - Hrvatska/Croatia, BCH - Bosna i Hercegovina/Bosnia and Herzegovina, HUN - Mađarska/Hungary,

G - Njemačka/Germany, RO - Rumunjska/Romania, CH - Švicarska/Switzerland, SRB - Srbija/Serbia

\section{REZULTATI}

\section{RESULTS}

Podaci o broju preživjelih biljaka po provenijencijama i blokovima prikazan je u tablici 3 , gdje se vidi da je najveći broj preživjelih biljaka u bloku 1 .
Prosječna visina za sve provenijencije iznosi 164,6 cm (slika 2). Najmanju prosječnu visinu ima provenijencija Alba Iulia iz Rumunije (9664) $104,2 \mathrm{~cm}$, a najveću provenijencija Dilj Čaglinski iz Hrvatske (9624) 197,4 cm, uz napomenu da je starost sadnica provenijencije Alba - Iulia pri osniva-

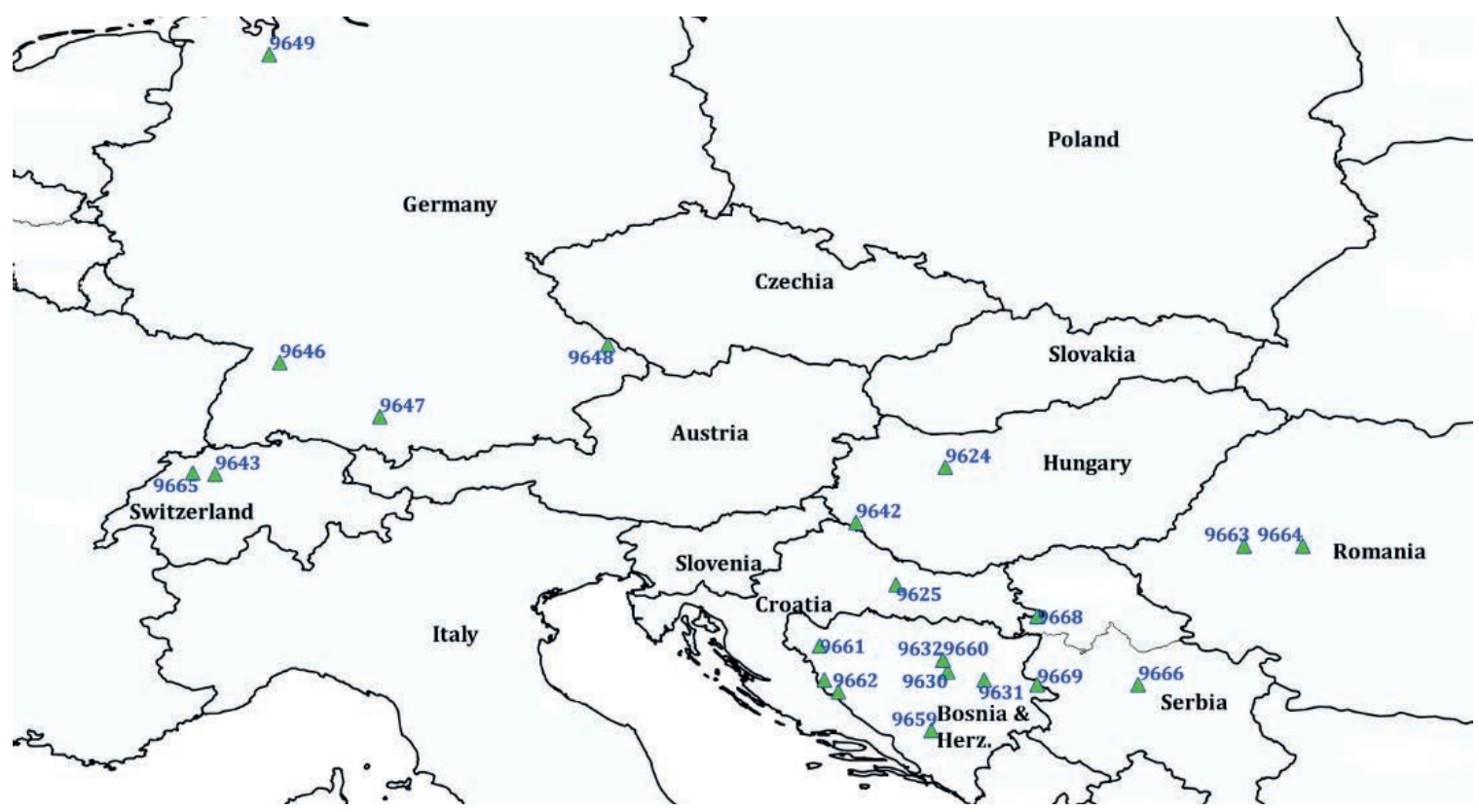

Slika 2: Mapa istraživanih provenijencija

Figure 2. Map of investigated provenances 
Tablica 2. Broj preživjelih biljaka po provenijencijama i blokovima Table 2. Number of survived plants per provenances and blocks

$\begin{array}{lcccc}\text { Provenijencija } & \begin{array}{c}\text { Blok 1 } \\ \text { Provenance }\end{array} & \begin{array}{c}\text { Blok 2 } \\ \text { Block 1 }\end{array} & \begin{array}{c}\text { Block 2 } \\ \text { Block 3 }\end{array} & \begin{array}{c}\text { Ukupno } \\ \text { Total }\end{array} \\ \text { B\&H - 9630 } & 38 & 25 & 7 & 70 \\ \text { B\&H - 9631 } & 31 & & & 31 \\ \text { B\&H - 9632 } & 31 & 8 & 9 & 48 \\ \text { B\&H - 9633 } & 35 & 14 & 20 & 69 \\ \text { B\&H - 9659 } & 20 & 7 & 1 & 28 \\ \text { B\&H - 9660 } & 24 & 1 & 4 & 29 \\ \text { B\&H - 9661 } & 8 & 11 & 6 & 25 \\ \text { B\&H - 9662 } & 17 & 18 & 18 & 53 \\ \text { CH - 9643 } & 35 & 8 & 22 & 65 \\ \text { CH - 9665 } & 12 & 7 & 4 & 23 \\ \text { CRO - 9624 } & 46 & 20 & 22 & 88 \\ \text { CRO - 9625 } & 37 & 24 & 19 & 80 \\ \text { GER - 9646 } & 10 & 11 & 5 & 26 \\ \text { GER - 9647 } & 24 & 26 & 33 & 83 \\ \text { GER - 9648 } & 18 & 26 & 8 & 52 \\ \text { GER - 9649 } & 29 & 30 & 20 & 79 \\ \text { HUN - 9642 } & 31 & 20 & 36 & 87 \\ \text { RO - 9663 } & 6 & 14 & 10 & 30 \\ \text { RO - 9664 } & 15 & 3 & & 18 \\ \text { SRB - 9666 } & 0 & 29 & 6 & 35 \\ \text { SRB - 9668 } & 9 & 20 & & 29 \\ \text { SRB - 9669 } & 24 & 8 & 2 & 34 \\ \text { Ukupno/Total } & 500 & 330 & 252 & 1082\end{array}$

nju pokusa bila dvije godine, a provenijencije Dilj Čaglinski tri godine. Najveće prosječne visine sve provenijencije pokazuju u bloku 1, što pokazuje kako mikrostanišni uvjeti na pojedinim blokovima i nehomogenost plohe utječu na rast biljaka.

Analiza varijanse pokazala je da postoje statistički značajne razlike između provenijencija za svojstvo visine biljaka (Sig. $<0.05$, Fizr, $>$ Ftab, tablica 3).

Duncanov multipli test za svojstvo visine pokazao je grupiranje provenijencija u sedam grupa, koje se međusobno preklapaju (tablica 4$)$.

Analiza varijance za svojstvo visine (tablica 5) pokazala je statistički značajne razlike na razini blokova, na razini provenijencija te na razini interakcije blok $\mathrm{x}$ populacija.

Prosječan promjer vrata korjena za sve provenijencije iznosi $33,4 \mathrm{~mm}$ (slika 3). Kao i za svojstvo visine, najmanji prosječan promjer ima provenijencija Alba Iulia iz Rumunije (9664) 22,6 mm, a najveći provenijencija Dilj Čaglinski iz Hrvatske (9624) 40,1 mm. Velika razlika u prosječnom promjeru može se djelomično objasniti različitom starošću sadnica pri osnivanju pokusa, kada su zasađene dvogodišnje sadnice provenijencije Alba Iulia i trogodišnje sadnice provenijencije Dilj Čaglinski. Kao i za svojstvo visine, najveći prosječan prečnik provenijencije imaju u bloku 1.

Tablica 3. Analiza varijanse za svojstvo visine biljaka

Table 3. Analysis of variance for height of plants

\begin{tabular}{|c|c|c|c|c|c|c|}
\hline $\begin{array}{l}\text { Izvor variranja } \\
\text { Source of variation }\end{array}$ & $\begin{array}{l}\text { Suma kvadrata } \\
\text { Sum of Squares }\end{array}$ & $\begin{array}{l}\text { Stupnjevi slobode } \\
\text { Degrees of freedom }\end{array}$ & $\begin{array}{l}\text { Sredina kvadrata } \\
\text { Mean Square }\end{array}$ & $\mathrm{F}$ & $\begin{array}{l}\text { Značajnost } \\
\text { Significance }\end{array}$ & $\begin{array}{l}\% \text { varijance/ } \\
\% \text { of Variance }\end{array}$ \\
\hline Between Groups & 517640,647 & 21 & 24649,555 & 6,133 & 0,000 & $12,80^{*}$ \\
\hline Within Groups & 4260220,766 & 1060 & 4019,076 & & & \\
\hline Total & 4777861,412 & 1081 & & & & \\
\hline
\end{tabular}

*preostalih 87,29\% varijance odnose se na sve ostale faktore, uključujući i grešku.

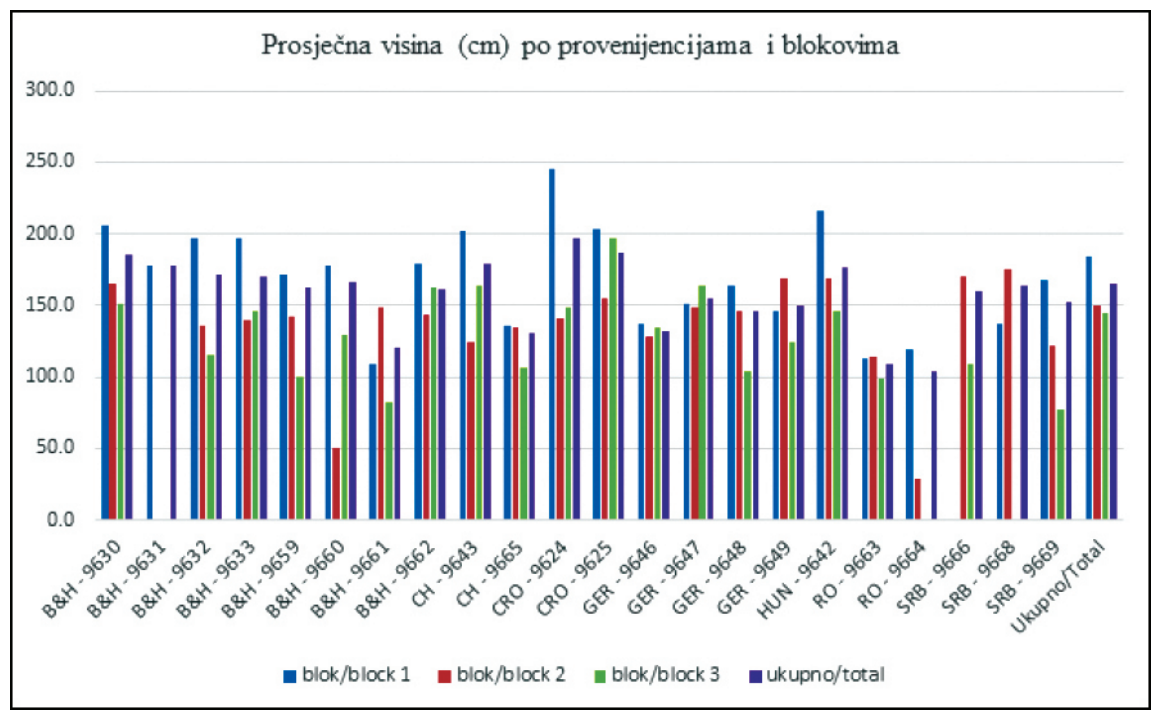

Slika 3. Prosječne visine po provenijencijama i blokovima

Figure 3. Average heights per provenances and blocks 
Tablica 4. Grupiranje provenijencija za svojstvo visina prema Duncanovom testu Table 4: Grouping of provenances by plant height $(\mathrm{cm})$ by Duncan test

\begin{tabular}{|c|c|c|c|c|c|c|c|c|}
\hline \multirow{2}{*}{$\begin{array}{l}\text { Provenijencija } \\
\text { Provenance }\end{array}$} & \multirow{2}{*}{$\mathrm{N}$} & \multicolumn{7}{|c|}{ Grupa/Group } \\
\hline & & 1 & 2 & 3 & 4 & 5 & 6 & 7 \\
\hline RO - 9664 & 18 & 104,2 & & & & & & \\
\hline $\mathrm{RO}-9663$ & 30 & 108,8 & & & & & & \\
\hline B\&H - 9661 & 25 & 120,0 & 120,0 & & & & & \\
\hline $\mathrm{CH}-9665$ & 23 & 130,2 & 130,2 & 130,2 & & & & \\
\hline GER - 9646 & 26 & 132,5 & 132,5 & 132,5 & & & & \\
\hline GER - 9648 & 52 & & 145,7 & 145,7 & 145,7 & & & \\
\hline GER - 9649 & 79 & & 149,3 & 149,3 & 149,3 & & & \\
\hline SRB - 9669 & 34 & & 152,0 & 152,0 & 152,0 & 152,0 & & \\
\hline GER - 9647 & 83 & & & 155,1 & 155,1 & 155,1 & 155,1 & \\
\hline SRB - 9666 & 35 & & & 160,0 & 160,0 & 160,0 & 160,0 & \\
\hline B\&H - 9662 & 53 & & & 161,1 & 161,1 & 161,1 & 161,1 & \\
\hline B\&H - 9659 & 28 & & & 162,0 & 162,0 & 162,0 & 162,0 & \\
\hline SRB - 9668 & 29 & & & 163,6 & 163,6 & 163,6 & 163,6 & \\
\hline B\&H - 9660 & 29 & & & & 166,9 & 166,9 & 166,9 & 166,9 \\
\hline B\&H - 9633 & 69 & & & & 170,6 & 170,6 & 170,6 & 170,6 \\
\hline B\&H - 9632 & 48 & & & & 171,7 & 171,7 & 171,7 & 171,7 \\
\hline HUN - 9642 & 87 & & & & 176,3 & 176,3 & 176,3 & 176,3 \\
\hline B\&H - 9631 & 31 & & & & 177,9 & 177,9 & 177,9 & 177,9 \\
\hline $\mathrm{CH}-9643$ & 65 & & & & 179,4 & 179,4 & 179,4 & 179,4 \\
\hline BदH - 9630 & 70 & & & & & 185,5 & 185,5 & 185,5 \\
\hline CRO - 9625 & 80 & & & & & & 187,3 & 187,3 \\
\hline CRO - 9624 & 88 & & & & & & & 197,4 \\
\hline Sig. & & 0,080 & 0,051 & 0,052 & 0,056 & 0,056 & 0,067 & 0,074 \\
\hline
\end{tabular}

Tablica 5. Two-way analiza varijanse za svojstvo visine biljaka Table 5. TWO-way Analysis of variance for height of plants

$\begin{array}{lccccc}\text { Izvor variranja } & \begin{array}{c}\text { Suma kvadrata tip III } \\ \text { Type III Sum of Squares }\end{array} & \begin{array}{c}\text { Stupnjevi slobode } \\ \text { Degrees of freedom }\end{array} & \begin{array}{c}\text { Sredina kvadrata } \\ \text { Mean Square }\end{array} & \text { F } & \begin{array}{c}\text { Značajnost } \\ \text { Significance }\end{array} \\ \text { Blok/Block } & 208466,716 & 2 & 104233,358 & 30,095 & 0,000 \\ \text { Populacija/Population } & 416500,503 & 21 & 19833,357 & 5,726 & 0,000 \\ \text { Blok*Populacija / Block*Population } & 386221,445 & 37 & 10438,417 & 3,014 & 0,000\end{array}$

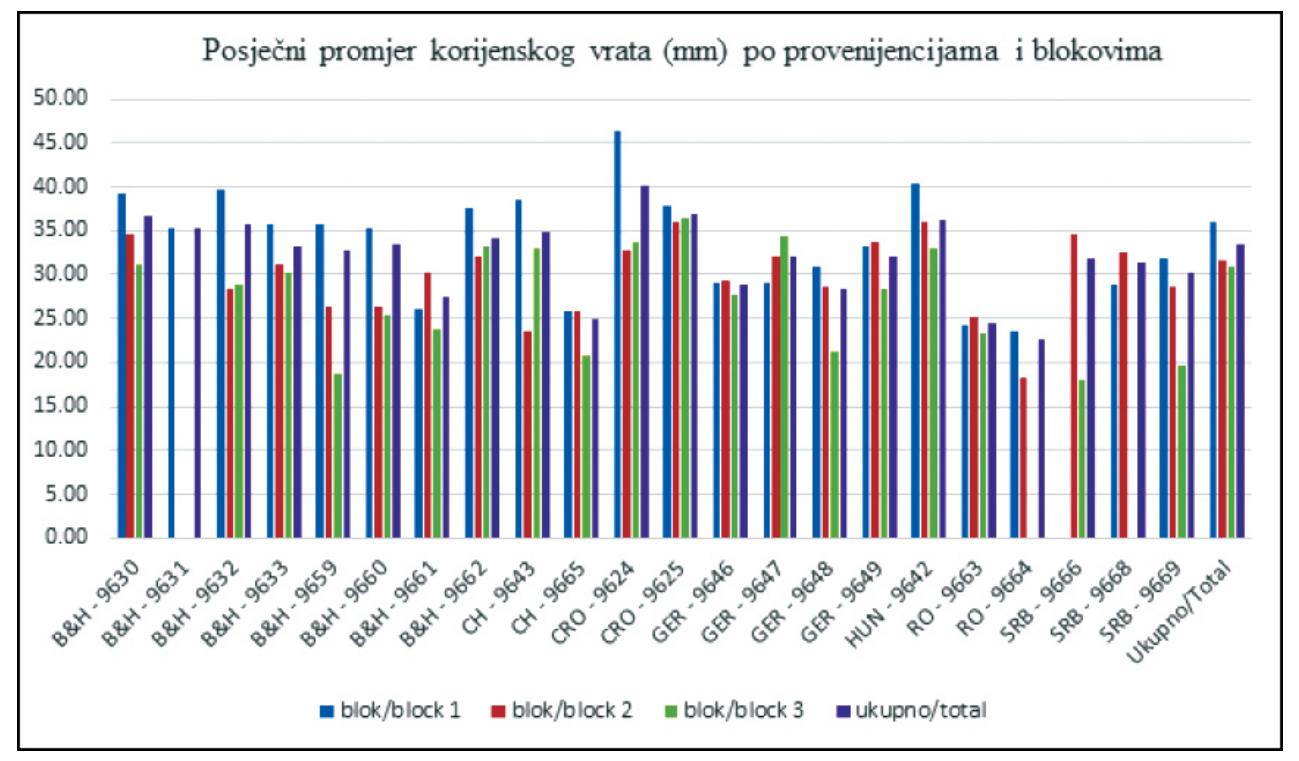

Slika 4. Prosjeci promjera vrata korijena po provenijencijama i blokovima

Figure 4. Average root collar diameters per provenances and blocks 
Tablica 6. Analiza varijanse za svojstvo promjer vrata korijena

Table 6: Analysis of variance for root collar diameters of plants

\begin{tabular}{|c|c|c|c|c|c|c|}
\hline $\begin{array}{l}\text { Izvor variranja } \\
\text { Source of variation }\end{array}$ & $\begin{array}{l}\text { Suma kvadrata } \\
\text { Sum of Squares }\end{array}$ & $\begin{array}{l}\text { Stupnjevi slobode } \\
d f\end{array}$ & $\begin{array}{l}\text { Sredina kvadrata } \\
\text { Mean Square }\end{array}$ & $F$ & $\begin{array}{c}\text { Značajnost } \\
\text { Signifikantnost }\end{array}$ & $\begin{array}{l}\% \text { varijance/ } \\
\% \text { of Variance }\end{array}$ \\
\hline Between Groups & 16750,048 & 21 & 797,621 & 7,189 & 0,000 & $13,34^{*}$ \\
\hline Within Groups & 117607,886 & 1060 & 110,951 & & & \\
\hline Total & 134357,934 & 1081 & & & & \\
\hline
\end{tabular}

*preostalih 86,66\% varijance odnose se na sve ostale faktore, uključujući i grešku.

Tablica 7. Grupiranje provenijencija za svojstvo promjer vrata korjena prema Duncan testu

Table 7: Grouping of provenances by diameter of root collar $(\mathrm{mm})$ by Duncan test

\begin{tabular}{|c|c|c|c|c|c|c|c|c|c|}
\hline \multirow{2}{*}{$\begin{array}{l}\text { Provenijencija } \\
\text { Provenance }\end{array}$} & \multirow{2}{*}{$\mathrm{N}$} & \multicolumn{8}{|c|}{ Grupe/Groups } \\
\hline & & 1 & 2 & 3 & 4 & 5 & 6 & 7 & 8 \\
\hline $\mathrm{RO}-9664$ & 18 & 22,6 & & & & & & & \\
\hline RO - 9663 & 30 & 24,4 & 24,4 & & & & & & \\
\hline $\mathrm{CH}-9665$ & 23 & 25,0 & 25,0 & & & & & & \\
\hline B\&H - 9661 & 25 & 27,4 & 27,4 & 27,4 & & & & & \\
\hline$D-9648$ & 52 & & 28,3 & 28,3 & 28,3 & & & & \\
\hline$D-9646$ & 26 & & 28,9 & 28,9 & 28,9 & 28,9 & & & \\
\hline SRB - 9669 & 34 & & & 30,3 & 30,3 & 30,3 & 30,3 & & \\
\hline SRB - 9668 & 29 & & & 31,4 & 31,4 & 31,4 & 31,4 & 31,4 & \\
\hline SRB - 9666 & 35 & & & 31,8 & 31,8 & 31,8 & 31,8 & 31,8 & \\
\hline$D-9647$ & 83 & & & 32,1 & 32,1 & 32,1 & 32,1 & 32,1 & \\
\hline$D-9649$ & 79 & & & 32,1 & 32,1 & 32,1 & 32,1 & 32,1 & \\
\hline B\&H - 9659 & 28 & & & 32,7 & 32,7 & 32,7 & 32,7 & 32,7 & \\
\hline B\&H - 9633 & 69 & & & & 33,2 & 33,2 & 33,2 & 33,2 & \\
\hline B\&H - 9660 & 29 & & & & 33,5 & 33,5 & 33,5 & 33,5 & \\
\hline B\&H - 9662 & 53 & & & & & 34,2 & 34,2 & 34,2 & \\
\hline $\mathrm{CH}-9643$ & 65 & & & & & & 34,7 & 34,7 & 34,7 \\
\hline BCH - 9631 & 31 & & & & & & 35,4 & 35,4 & 35,4 \\
\hline B\&H - 9632 & 48 & & & & & & 35,7 & 35,7 & 35,7 \\
\hline $\mathrm{H}-9642$ & 87 & & & & & & & 36,3 & 36,3 \\
\hline B\&H - 9630 & 70 & & & & & & & 36,8 & 36,8 \\
\hline CRO - 9625 & 80 & & & & & & & 36,9 & 36,9 \\
\hline CRO - 9624 & 88 & & & & & & & & 40,1 \\
\hline Sig. & & 0,070 & 0,091 & 0,057 & 0,067 & 0,067 & 0,063 & 0,058 & 0,052 \\
\hline
\end{tabular}

Tablica 8. Two-way naliza varijanse za svojstvo promjer vrata korijena

Table 8. Two-way variance analyisi for root collar diameter

\begin{tabular}{lccccc} 
Izvor variranja & $\begin{array}{c}\text { Suma kvadrata tip III } \\
\text { Sype III Sum of Squares }\end{array}$ & $\begin{array}{c}\text { Stupnjevi slobode } \\
\text { Degrees of freedom }\end{array}$ & $\begin{array}{c}\text { Sredina kvadrata } \\
\text { Mean Square }\end{array}$ & $\begin{array}{c}\text { F } \\
\text { Značajnost } \\
\text { Significance }\end{array}$ \\
\hline Blok/Block & 3743,653 & 2 & 1871,826 & 18.338 & 0,000 \\
Populacija/Population & 13652,279 & 21 & 650,109 & 6.369 & 0,000 \\
Blok*Populacija/Block*Population & 7940,321 & 37 & 214,603 & 2.102 & 0,000
\end{tabular}

Analiza varijanse pokazala je da postoje statistički značajne razlike između populacija za svojstvo promjer vrata korijena (tablica 6).

Duncanov multipli test za promjer vrata korijena pokazao je grupiranje provenijencija u osam grupa (tablica 7).

Two-way analiza varijanse za svojstvo promjer vrata korijena (tablica 8) pokazala je statistički značajne razlike na razini blokova, na razini populacija, kao i na razini interakcije blok x populacija.

Vizualna praćenja karakterističnih fenoloških faza povećava mogućnost veće pogreške u odnosu na mjerenje instrumen- tom. To se posebno odnosi na evidentiranje onih fenoloških faza koje se teže uočavaju i na prijelazu su između dvije faze. Rezultati fenoloških istraživanja provenijencija obične bukve u međunarodnom pokusu kod Kaknja pokazali su značajne razlike u vremenu početka, trajanja i završetka listanja, što je potvrđeno provedenim analizama varijance.

Na temelju promatranih fenoloških faza listanja, kao početak vegetacije kod obične bukve u ovom međunarodnom pokusu 2017. godine može se uzeti datum 10. travnja, jer je kod dvanaest provenijencija započelo otvaranje pupova (tablica 9). 
Tablica 9. Datumi najranijeg i najkasnijeg pojavljivanja fenofaza

Table 9. Dates of the earliest and the latest occur of phenological stages of leafing

\begin{tabular}{|c|c|c|c|c|c|c|c|c|c|c|}
\hline \multirow[b]{2}{*}{$\begin{array}{l}\text { Provenijencija } \\
\text { Provenance }\end{array}$} & \multicolumn{10}{|c|}{ Fenofaza/Phenophase } \\
\hline & $\begin{array}{c}\text { A } \\
\text { najkasnije } \\
\text { latest }\end{array}$ & $\begin{array}{c}\text { B } \\
\text { najranije } \\
\text { earliest }\end{array}$ & $\begin{array}{c}\text { B } \\
\text { najkasnije } \\
\text { latest }\end{array}$ & $\begin{array}{c}\text { C } \\
\text { najranije } \\
\text { earliest }\end{array}$ & $\begin{array}{c}\text { C } \\
\text { najkasnije } \\
\text { latest }\end{array}$ & $\begin{array}{c}\text { D } \\
\text { najranije } \\
\text { earliest }\end{array}$ & $\begin{array}{c}\text { D } \\
\text { najkasnije } \\
\text { latest }\end{array}$ & $\begin{array}{c}\text { E } \\
\text { najranije } \\
\text { earliest }\end{array}$ & $\begin{array}{c}\mathrm{E} \\
\text { najkasnije } \\
\text { latest }\end{array}$ & $\begin{array}{c}\text { F } \\
\text { najranije } \\
\text { earliest }\end{array}$ \\
\hline B\&H - 9630 & 20.05. & 04.04. & 01.05. & 10.04. & 01.05. & 24.04. & 08.05 & 24.04. & 15.05. & 08.05 \\
\hline B\&H - 9631 & 20.05 & 10.04 & 01.05 & 10.04 & 01.05. & 24.04. & 08.05 & 01.05. & 08.05 & 08.05 \\
\hline B\&H - 9632 & 20.05. & 10.04 & 01.05 & 10.04 & 08.05 & 10.04 & 08.05 & 24.04. & 15.05 & 08.05. \\
\hline B\&H - 9633 & 20.05 & 31.03. & 01.05. & 04.04. & 24.04. & 10.04. & 08.05. & 10.04. & 15.05. & 08.05. \\
\hline B\&H - 9659 & 20.05 & 24.04. & 01.05 & 24.04. & 01.05 & 01.05. & 15.05 & 08.05 & 15.05 & 08.05. \\
\hline B\&H - 9660 & 10.04 & 10.04 & 24.04 . & 24.04 . & 01.05 & 01.05 & 01.05 & 08.05 & 15.05 & 08.05. \\
\hline B\&H - 9661 & 20.05 . & 31.03. & 15.05 & 04.04 & 15.05. & 10.04 & 15.05 & 10.04 & 15.05 & 01.05. \\
\hline B\&H - 9662 & 20.05. & 31.03. & 01.05 & 10.04 & 01.05 & 24.04. & 08.05 & 24.04. & 15.05. & 08.05. \\
\hline CH - 9643 & 20.05 & 10.04 & 08.05 & 24.04. & 08.05 & 24.04. & 15.05 & 01.05. & 15.05. & 08.05 \\
\hline CH - 9665 & 20.05. & 10.04 & 01.05 & 24.04. & 08.05. & 01.05. & 08.05. & 01.05. & 15.05. & 08.05. \\
\hline CRO - 9624 & 20.05. & 10.04. & 01.05. & 10.04. & 08.05. & 24.04. & 08.05. & 01.05. & 15.05. & 08.05. \\
\hline CRO - 9625 & 20.05. & 04.04. & 01.05. & 10.04. & 08.05. & 24.04. & 08.05 & 01.05. & 15.05. & 08.05. \\
\hline D - 9646 & 20.05. & 10.04. & 24.04. & 10.04. & 08.05 & 24.04. & 15.05. & 24.04. & 15.05. & 08.05. \\
\hline D - 9647 & 20.05. & 10.04. & 15.05. & 10.04. & 15.05. & 24.04. & 20.05 & 01.05. & 15.05. & 08.05. \\
\hline D - 9648 & 20.05. & 04.04. & 24.04. & 10.04. & 01.05. & 24.04. & 08.05. & 24.04. & 15.05. & 08.05. \\
\hline D - 9649 & 20.05. & 10.04 & 08.05. & 24.04 . & 08.05. & 24.04. & 15.05. & 01.05. & 15.05. & 08.05. \\
\hline H - 9642 & 20.05. & 04.04. & 01.05. & 10.04. & 08.05. & 10.04. & 08.05. & 24.04. & 15.05. & 01.05. \\
\hline RO - 9663 & 20.05. & 24.04. & 01.05. & 24.04. & 01.05. & 01.05. & 08.05. & 01.05. & 15.05. & 08.05. \\
\hline RO - 9664 & 10.04 & 10.04 & 24.04. & 10.04. & 01.05. & 24.04. & 08.05. & 01.05. & 15.05. & 08.05 \\
\hline SRB - 9666 & 24.04. & 24.04. & 01.05. & 24.04. & 08.05. & 24.04 & 08.05. & 01.05. & 15.05. & 08.05. \\
\hline SRB - 9668 & 24.04. & 10.04. & 01.05. & 24.04. & 01.05. & 24.04. & 08.05. & 01.05. & 15.05. & 08.05. \\
\hline SRB - 9669 & 20.05. & 31.03. & 24.04. & 04.04. & 01.05. & 10.04. & 08.05. & 24.04. & 15.05. & 08.05. \\
\hline
\end{tabular}

Najranije su u fazu B ušle dvije bosanskohercegovačke provenijencije (Grmeč Jasenica i Dinara) i provenijencija Cer iz Srbije, 31.03., a najkasnije provenijencija Bugojno Vranica Bistrica iz Bosne i Hercegovine, Alesd iz Rumunije i Avala iz Srbije., 24.4.

$\mathrm{U}$ fazu C najranije su ušle provenijencije Grmeč Jasenica iz Bosne i Hercegovine i Cer iz Srbije, 4.4., dok su ostale provenijencije ušle u ovu fazu 10.4. ili 24.4.

U fazu D najranije su ušle provenijencije bosanskohercegovačke provenijencije Tešanj Crni Vrh I i Grmeč Jasenica, mađarska provenijencija Valkonya i srbijanska provenijencija Cer, 10.04., a najkasnije tri bosanskohercegovačke provenijencije (Bugojno Vranica Bistrica, Tešanj Crni Vrh II, Bosanska Krupa Bastra Ćorkovača), rumunska provenijencija Alesd i švicarska provenijencija Sihlwald, 1.5.

Provenijencija Grmeč Jasenica je najranije ušla u fazu E, 10.4., znatno ranije od ostalih provenijencija koje su ušle u ovu fazu 24.4. ili 1.5., a dvije provenijencije iz Bosne i Hercegovine tek 8.5. (Bugojno Vranica Bistrica, Tešanj Crni Vrh II).

Mađarska provenijencija Valkonya najranije je ušla u fazu F, 1.5., a sve ostale provenijencije 8.5. U istraživanju Ballian i sur. (2015) fenofaza F se najranije pojavila 2. svibnja kod hrvatskih provenijencija Dilj Čanglinski, Vrani kamen, bosanskohercegovačkih Tajan - Zavidovići, Konjuh - Kladanj, Te- šanj - Crni Vrh I, Grmeč - Jasenica, Tešanj - Crni Vrh II, Dinara, mađarske provenijencije Valkonya), njemačke provenijencije BW Wildbad., i srbijanskih Avala, Fruška gora i Cer, a najkasnije njemačke provenijencije BW Schwaeb. Alb i NS Hasbruch i bosanskohercegovačka Bugojno Vranica Bistrica. Poslije 9. svibnja su sve bilike izlistale.

Dužina trajanja fenoloških faza prikazana je u tablici 10.

Dužinu trajanja faze A nismo računali, jer ona ustvari obuhvata cijeli period mirovanja vegetacije.

Faza B prosječno je trajala 3-11 dana. Najduže prosječno trajanje faze B imala je provenijencija bosanskohercegovačka provenijencija Tešanj Crni Vrh II, a najkraće bosanskohercegovačka provenijencija Bugojno Vranica Bistrica.

Faza C prosječno je trajala 2-7 dana. Najduže prosječno trajanje faze C imala je provenijencija Cer iz Srbije, a najkraće Bugojno Vranica Bistrica iz Bosne i Hercegovine.

Faza D prosječno je trajala 2-7 dana. Najduže prosječno trajanje faze D imala je domaća provenijencija Tešanj Crni Vrh II i rumunjska Alba Iulia, a najkraće bosanskohercegovačka Konjuh, Kladanj.

Faza E prosječno je trajala 3-6 dana. Najduže prosječno trajanje faze $\mathrm{E}$ imale su bosanskohercegovačke provenijencije Tajan Zavidovići i Tešanj Crni Vrh II, njemačka provenijencija BY Höllerbach i rumunjska Alba Iulia, a najkraće bosanskohercegovačka Konjuh, Kladanj. 
Tablica 10. Trajanje fenoloških faza (dani)

Table 10. Duration of phenological stages (days)

\begin{tabular}{|c|c|c|c|c|c|c|c|c|c|c|c|}
\hline \multirow[b]{2}{*}{$\begin{array}{l}\text { Provenijencija } \\
\text { Provenance }\end{array}$} & \multirow[b]{2}{*}{$\mathrm{N}$} & \multicolumn{2}{|c|}{ Faza B/Phase $B$} & \multicolumn{2}{|c|}{ Faza C/Phase C } & \multicolumn{2}{|c|}{ Faza D/Phase D } & \multicolumn{2}{|c|}{ Faza E/Phase E } & \multicolumn{2}{|c|}{ Faza F/Phase F } \\
\hline & & $\begin{array}{c}\text { Prosjek } \\
\text { Mean }\end{array}$ & $\begin{array}{l}\text { Standardna } \\
\text { devijacija } \\
\text { Standard } \\
\text { deviation }\end{array}$ & $\begin{array}{l}\text { Prosjek } \\
\text { Mean }\end{array}$ & $\begin{array}{l}\text { Standardna } \\
\text { devijacija } \\
\text { Standard } \\
\text { deviation }\end{array}$ & $\begin{array}{c}\text { Prosjek } \\
\text { Mean }\end{array}$ & $\begin{array}{c}\text { Standardna } \\
\text { devijacija } \\
\text { Standard } \\
\text { deviation }\end{array}$ & $\begin{array}{c}\text { Prosjek } \\
\text { Mean }\end{array}$ & $\begin{array}{c}\text { Standardna } \\
\text { devijacija } \\
\text { Standard } \\
\text { deviation }\end{array}$ & $\begin{array}{l}\text { Prosjek } \\
\text { Mean }\end{array}$ & $\begin{array}{c}\text { Standardna } \\
\text { devijacija } \\
\text { Standard } \\
\text { deviation }\end{array}$ \\
\hline В\&H - 9630 & 71 & 9 & 4,3 & 5 & 4,8 & 6 & 3,6 & 6 & 4,3 & 12 & 5,6 \\
\hline B\&H - 9631 & 31 & 8 & 7,8 & 5 & 5,8 & 2 & 3,5 & 3 & 3,6 & 9 & 2,3 \\
\hline B\&H - 9632 & 48 & 6 & 5,5 & 6 & 4,5 & 6 & 3,4 & 5 & 5,4 & 10 & 3,8 \\
\hline B\&H - 9633 & 69 & 7 & 5 & 5 & 4,6 & 5 & 3,8 & 5 & 5,8 & 9 & 4,9 \\
\hline В\&H - 9659 & 28 & 3 & 4,5 & 2 & 3,2 & 5 & 3,3 & 5 & 3,1 & 9 & 4,2 \\
\hline B\&H - 9660 & 29 & 11 & 4,9 & 6 & 4,8 & 7 & 1,8 & 6 & 2,5 & 10 & 2,5 \\
\hline В\&H - 9661 & 24 & 5 & 5,2 & 5 & 4,9 & 4 & 3,5 & 5 & 3,4 & 12 & 4,4 \\
\hline B\&H - 9662 & 52 & 10 & 3,5 & 3 & 4,2 & 6 & 3,9 & 5 & 4,2 & 11 & 5,1 \\
\hline $\mathrm{CH}-9643$ & 65 & 8 & 5,1 & 5 & 4,3 & 5 & 3,2 & 5 & 2,9 & 7 & 5,3 \\
\hline CH - 9665 & 23 & 9 & 4 & 6 & 3,9 & 5 & 3,6 & 5 & 3,2 & 7 & 5 \\
\hline CRO - 9624 & 88 & 8 & 4,5 & 6 & 5 & 6 & 3,4 & 4 & 3,4 & 12 & 5,2 \\
\hline CRO - 9625 & 80 & 10 & 4,1 & 5 & 4,7 & 5 & 3,8 & 5 & 3,7 & 11 & 5 \\
\hline D - 9646 & 26 & 6 & 5,2 & 6 & 5 & 6 & 3,9 & 5 & 4,3 & 13 & 5,3 \\
\hline D - 9647 & 83 & 8 & 4,2 & 5 & 4,3 & 6 & 3,4 & 5 & 3,2 & 6 & 4,6 \\
\hline D - 9648 & 52 & 5 & 5,2 & 5 & 5,9 & 6 & 4,3 & 6 & 5,1 & 13 & 5,2 \\
\hline D - 9649 & 79 & 8 & 4 & 5 & 4,5 & 6 & 3,2 & 5 & 3,3 & 8 & 5,4 \\
\hline H - 9642 & 87 & 9 & 5,2 & 5 & 4,1 & 6 & 3,5 & 5 & 4,1 & 8 & 5,2 \\
\hline RO - 9663 & 30 & 6 & 4,9 & 5 & 4,9 & 4 & 3,5 & 4 & 3,2 & 11 & 6,2 \\
\hline RO - 9664 & 18 & 8 & 4,5 & 5 & 6,2 & 7 & 3,7 & 6 & 2,7 & 12 & 4,2 \\
\hline SRB - 9666 & 35 & 8 & 3,8 & 6 & 4,6 & 6 & 2,8 & 5 & 3,2 & 7 & 5,7 \\
\hline SRB - 9668 & 29 & 10 & 3,5 & 4 & 4,5 & 6 & 3 & 4 & 3,4 & 11 & 4,4 \\
\hline SRB - 9669 & 33 & 9 & 4,5 & 7 & 4,3 & 4 & 4,1 & 5 & 5,1 & 12 & 4,4 \\
\hline Total & 1080 & 8 & 4,9 & 5 & 4,7 & 5 & 3,6 & 5 & 4,0 & 10 & 5,3 \\
\hline
\end{tabular}

Tablica 11. Analiza varijanse za dužinu trajanja fenoloških faza

Table 11. Variance analysis for duration of phenological stages

\begin{tabular}{|c|c|c|c|c|c|c|c|}
\hline $\begin{array}{l}\text { Trajanje fenofaze } \\
\text { Duration of } \\
\text { phenophase }\end{array}$ & $\begin{array}{c}\text { Izvor variranja } \\
\text { Source of variation }\end{array}$ & $\begin{array}{l}\text { Suma kvadrata } \\
\text { Sum of Squares }\end{array}$ & $\begin{array}{c}\text { Stupnjevi } \\
\text { slobode } \\
\text { df }\end{array}$ & $\begin{array}{c}\text { Sredina } \\
\text { kvadrata } \\
\text { Mean Square }\end{array}$ & $\mathrm{F}$ & $\begin{array}{c}\text { Značajnost } \\
\text { Signifikantnost }\end{array}$ & $\begin{array}{c}\text { Broj grupa po } \\
\text { Duncan testu } \\
\text { Duncan - number } \\
\text { of groups }\end{array}$ \\
\hline \multirow{4}{*}{ Phase A } & Between Groups & 11181,953 & 21 & 532,474 & 6,157 & 0,000 & \\
\hline & Within Groups & 91504,113 & 1058 & 86,488 & & & 9 \\
\hline & Total & 102686,066 & 1079 & & & & \\
\hline & Between Groups & 2815,708 & 21 & 134,081 & 6,072 & 0,000 & \\
\hline \multirow[t]{3}{*}{ Phase B } & Within Groups & 23362,944 & 1058 & 22,082 & & & 8 \\
\hline & Total & 26178,652 & 1079 & & & & \\
\hline & Between Groups & 848,348 & 21 & 40,398 & 1,854 & 0,011 & \\
\hline \multirow[t]{3}{*}{ Phase C } & Within Groups & 23053,204 & 1058 & 21,789 & & & 3 \\
\hline & Total & 23901,552 & 1079 & & & & \\
\hline & Between Groups & 629,120 & 21 & 29,958 & 2,414 & 0,000 & \\
\hline \multirow[t]{3}{*}{ Phase D } & Within Groups & 13132,347 & 1058 & 12,412 & & & 5 \\
\hline & Total & 13761,467 & 1079 & & & & \\
\hline & Between Groups & 333,158 & 21 & 15,865 & 1,011 & 0,447 & \\
\hline \multirow[t]{3}{*}{ Phase E } & Within Groups & 16609,360 & 1058 & 15,699 & & & 3 \\
\hline & Total & 16942,519 & 1079 & & & & \\
\hline & Between Groups & 5052,822 & 21 & 240,611 & 9,881 & 0,000 & \\
\hline \multirow[t]{2}{*}{ Phase F } & Within Groups & 25762,363 & 1058 & 24,350 & & & 8 \\
\hline & Total & 30815,185 & 1079 & & & & \\
\hline
\end{tabular}


Faza F nije završena kod svih provenijencija, te smo izračunali prosječnu dužinu trajanja do datuma posljednjeg osmatranja. Prosječno je trajala 6-13 dana. Najduže je trajala kod provenijencija njemačkih provenijencija BW Wildbad i BY Höllerbach, a najkraće kod njemačke provenijencije BW Schwäb. Alb.

Analiza varijanse za dužinu trajanja fenoloških faza pokazuje statistički značajne razlike između istaživanih provenijencija za sve fenološke faze (tablica 11).

\section{RASPRAVA}

\section{DISCUSSION}

Ivanković i sur. (2008) istraživali su varijabilnost visinskog rasta provenijencija obične bukve u dva terenska pokusa smještena u Hrvatskoj i Sloveniji. Rezultati analize varijanse pokazali su da je efekt provenijencija bio statistički značajan samo u slovenskom testu.

Hoffman (1961) navodi da se dostignute visine ne mogu uzeti kao sasvim pouzdana mjera kojom se može točno utvrditi rast određenih provenijencija, jer često dolazi do promjene stope rasta u kasnijoj dobi, što je potvrdio i Pintarić (2000) u istraživanju rasta provenijencija ariša, dok mi to u našem istraživanju još nismo registrirali. Ovdje je važno naglasiti da su Vidaković i Krstinić (1985) izvijestili da se ne može sa sigurnošću govoriti o rastu provenijencija bukve do starosti 40 godina ili jedne trećine produkcionog perioda.

Prema Larsenu (1985), na osnovi ranih testova može se predvidjeti da će određene provenijencije bukve zadržati dobar rast u kasnijem životnom dobu. Njegova istraživanja su pokazala da idući od sjevernog prema južnom dijelu areala bukva pokazuje bolji rast.

U ovom istraživanju najmanju prosječnu visinu ima provenijencija Alba - Iulia iz Rumunije $104.2 \mathrm{~cm}$, a najveću provenijencija Dilj Čaglinski iz Hrvatske $197.4 \mathrm{~cm}$. Ovi rezultati su u skladu s rezultatima Ballian i Zukić 2011. godine na istom testu provenijencija, kad je najnižu prosječnu visinu imala provenijencije Alba Iulia $(43.48 \mathrm{~cm})$, a najveću Dilj Čaglinski (93.21 cm). Ballian i Jukić (2014-15) su istraživali uporedne pokazatelje rasta provenijencija u 2009. i 2014. godini. U 2009. godini najmanju prosječnu visinu imala je provenijencija Alba - Iulia, a najvišu Dilj Čaglinski. U 2014. godini je provenijencija Alba - Iulia također imala najmanju visinu, a najveću Dilj Čaglinski.

Kao i za svojstvo visine, najmanji prosječan promjer ima provenijencija Alba Iulia iz Rumunije $22.6 \mathrm{~mm}$, a najveći provenijencija Dilj Čaglinski iz Hrvatske $40.1 \mathrm{~mm}$, što je u skladu s rezultatima Ballian i Zukić (2011). U istraživanju Ballian i Jukić (2014-15) najmanji prosječni promjer vrata korijena u 2009. godini imala je rumunska provenijencija Alba - Iulia, a 2014. godine švicarska provenijencija Sihlwald.
Najveći prosječan promjer vrata korijena 2009. i 2014. godine imala je provenijencija Dilj Čaglinski 27,34 mm.

U istraživanju koje su proveli Bogunović i dr. (2020) u testu provenijencija obične bukve u Hrvatskoj, najvišu prosječnu vrijednost visinskog prirasta također je pokazala hrvatska provenijencija HR24 (Sjeverni Dilj Čaglinski), dok je najniži prosječan visinski prirast imala jedna provenijencija iz Njemačke. Rezultati studije pokazali su znatno bolju prilagođenost provenijencija podrijetlom s većih, kao i nešto malo nižih visina u odnosu na mjesto pokusa, ali koje su toplije i sušnije tijekom ljetne sezone.

Kao početak vegetacije kod obične bukve u ovom međunarodnom pokusu 2017. godine može se uzeti datum 10. travanj, što je u skladu s rezultatima koje su dobili Ballian i sur. (2015) godine za 2014. godinu u istom testu provenijencija

Faza B se u ovom istraživanju javlja već 31.3. (bh provenijencije Grmeč Jasenica i Dinara, srbijanska provenijencija Cer), dok se u istraživanju Ballian i sur. (2015) ova faza javlja najranije 14.4. (hrvatska provenijencija Dilj Čaglinski, bh provenijencije Tajan, Konjuh, Crni Vrh I, mađarska Valkonya i srbijanska Cer).

Faza B se u ovom istraživanju najkasnije javlja 24.4. (bh provenijencija Bugojno, rumunjska Alesd, srbijanska Avala), a u istraživanju Ballian i sur. (2015), faza B javlja se najkasnije 25.4. (njemačke provenijencije BW Schwaeb. Alb i NS Hasbruch te bh provenijencije Bugojno).

Petkova i sur. (2017) su istraživali proljetnu i jesenju fenologiju bugarskih i njemačkih provenijencija obične bukve pod sličnim klimatskim uvjetima, i to za 2013. i 2016. godinu. Rezultati su pokazali da bugarske provenijencije listaju ranije nego njemačke u oba promatrana perioda. Geografska dužina je imala najveći utjecaj na listanje.

Mađarska provenijencija Valkonya najranije je ušla u fazu F, 01.05., a sve ostale provenijencije 8.5. U istraživanju Ballian i sur. (2015) fenofaza F se najranije pojavila 2. svibnja kod hrvatskih provenijencija Dilj Čaglinski, Vrani kamen, bosanskohercegovačkih Tajan - Zavidovići, Konjuh - Kladanj, Tešanj - Crni Vrh I, Grmeč - Jasenica, Tešanj - Crni Vrh II, Dinara, mađarske provenijencije Valkonya), njemačke provenijencije BW Wildbad., i srbijanskih Avala, Fruška gora i Cer, a najkasnije njemačke provenijencije BW Schwaeb. Alb i NS Hasbruch i bosanskohercegovačka Bugojno Vranica Bistrica. Poslije 9. svibnja su sve biljke izlistale.

Za razliku od rezultata koje su dobili Ballian i sur. (2015), ovo istraživanje nije pokazalo da provenijencije iz Bosne i Hercegovine i Hrvatske listaju ranije od ostalih, a za pouzdanije zaključke zašto je došlo do ovakvih razlika bit će potrebno izvršiti dodatna istraživanja koja će uključivati i klimatske parametre. Gračan i sur. (2006) u istraživanju u međunarodnom pokusu provenijencija osnovanom u Hrvatskoj, u koji su uključene biljke 36 različitih provenijencija obične bukve: 15 iz Hrvatske, 3 iz Slovenije i 18 iz 11 
europskih zemalja, utvrdili su da su domaće (hrvatske) provenijencije u pravilu ranije listaju od stranih.

Urbani (1914) ističe da u gorskim krajevima cvatnja kasni 3-4 dana s porastom od svakih 100 metara nadmorske visine, dok je Brinar (1976) u Sloveniji došao do saznanja da listanje kasni za jedan dan ako su razlike u nadmorskoj visini višoj od $122 \mathrm{~m}$. Chmura i Rozkowski (2002) u testu provenijencija u Poljskoj, koji je sadržavao 38 provenijencija, utvrdili su da istočne provenijencije listaju ranije, te da geografska dužina i širina također značajno utječu na fenologiju, te da sjeverne populacije listaju i završavaju sezonu rasta kasnije, kao i one s viših nadmorskih visina. $\mathrm{U}$ ovom istraživanju se nije pokazalo da provenijencije s nižih nadmorskih visina ranije počinju listati.

Prosječno trajanje fenofaza u ovom istraživanju drukčije je od onoga koje su dobili Ballian i sur. (2015). Faza B prosječno je trajala 3-11 dana, dok je u istraživanju Ballian i sur. (2015) prosječno trajanje ove fenofaze 15 dana. Faza C prosječno je trajala 2-7 dana, dok je prosječno trajanje ove fenofaze u istraživanju Ballian i sur. (2015) bilo je 15 dana. Faza D prosječno je trajala 2-7 dana. Prosječno trajanje ove fenofaze u istraživanju Ballian i sur. (2015) bilo je 13 dana. Faza E prosječno je trajala 3-6 dana. Prosječno trajanje ove fenofaze u istraživanju Ballian i sur. (2015) bilo je 10 dana. Prosječno trajanje fenofaza razlikuje se $\mathrm{u}$ dva istraživanja na istom testu provenijencija, što upućuje na potrebu dodatnih istraživanja koja će uključiti klimatske parametre.

Rezultati istraživanja početka listanja obične bukve posebno su značajni na područjima gdje postoji opasnost od pojave kasnog mraza. Kako navode Teissier Du Cros i sur., 1988 u rezultatima svojih istraživanja otvaranje pupova je pod strogom genetskom kontrolom.

\section{ZAKLJUČCI CONCLUSIONS}

Analiza varijanse za morfološka svojstva visinu i promjer vrata korijena pokazala je statistički značajnu razliku između provenijencija.

Provenijencija Dilj Čaglinski iz Hrvatske dostigla je najveću prosječnu visinu i promjer, a provenijencija Alba - Iulia iz Rumunije najmanji.

Da bismo odredili tendencije rasta pojedinih provenijencija u sljedećim fazama razvoja, trebamo nastaviti mjerenja morfoloških karakteristika, kao i provesti istraživanja provenijencija na molekularnoj razini.

Rezultati ove studije mogu poslužiti za utvrđivanje juvenilnoadultne korelacije morfoloških svojstava obične bukve.

$\mathrm{Na}$ temelju istraživanih fenoloških svojstava utvrđeno je postojanje statistički značajne varijabilnosti između svih istraživanih provenijencija.

Nije utvrđeno da provenijencije s nižih nadmorskih visina ranije listaju.
Utvrđene su statistički značajne razlike u početku, trajanju i završetku pojedinih fenofaza.

Kao početak vegetacije obične bukve u ovom međunarodnom pokusu za 2017. godinu može se uzeti 10. travanj, jer je kod dvanaest od 22 provenijencije ovoga dana započelo otvaranje pupova. Potrebno je provoditi višegodišnja istraživanja kako bi se došlo do zaključka o očekivanom periodu početka vegetacije u međunarodnom pokusu provenijencija obične bukve kod Kaknja.

\section{LITERATURA}

\section{REFERENCES}

- Ballian, D., Zukić, N., 2011: Analysis of the growth of common beech provenances (Fagus sylvatica L.) in the international experiment near Kakanj. Radovi Šumarskog fakulteta u Sarajevu, $41(2): 75-91$

- Ballian, D., Jukić, B. 2014-15: Usporedni pokazatelji uspijevanja bukve (Fagus sylvatica L.) u međunarodnom pokusu Kakanj za 2009. i 2014. godinu, Radovi Hrvatskoga društva za znanost i umjetnost Radovi hrvatskog društva za znanost i umjetnost, 16/17: 200-215.

- Ballian, D., Jukić, B., Balić, B., Kajba D., Von Wüehlisch, G., 2015: Fenološka varijabilnost obične bukve (Fagus sylvatica L.) u međunarodnom testu provenijencija, Šumarski List, 11-12 (2015): 521-533

- Ballian, D., Westergren, M., Kraigher, H., 2019: Varijabilnost obične bukve (Fagus sylvatica L.) u Bosni i Hercegovini. UšitSilva slovenica. (Str. 1-229)

- Bogunović S, Bogdan S, Lanšćak M, Ćelepirović N, Ivanković M, 2020: Use of a Common Garden Experiment in Selecting Adapted Beech Provenances for Artificial Stand Restoration. Southeast Eur for 11(1): early view. https://doi.org/10.15177/ seefor.20-07.Brinar, M., 1976: O razvojnom ritmu različitih bukovih provenienc ekotipov. Gozd. Vest., 21(3-4): 65-90.

- Chmura, D.J., Rozkowski, R., 2002: Variability of beech provenances in spring and autumn phenology, Silvae Genetica 51(2):123-127

- Forstreuter, M., 2002: Auswirkungen globaler Klimaänderungen auf das Wachstum und den Gaswechsel $(\mathrm{CO} 2 / \mathrm{H} 2 \mathrm{O})$ von Rotbuchenbeständen (Fagus sylvatica L.). Berlin, Germany: TU Berlin.

- Gračan, J., Ivanković, M., Marijanović, H., Perić, S. 2006: Istraživanje uspijevanja provenijencija domaćih i stranih vrsta drveća, s osvrtom na međunarodni pokus provenijencija obične bukve (Fagus sylvatica L.). Radovi Šumarskog instituta Jastrebarsko br. 9: 337-352.

- Hoffmann, J. (1961): Ergebnisse eines Anbauversuches mit Buchen verschiedener Herkünfte in Tharandter Wald. Fortstwiss. Cbl., 80 (7 - 8): 240 - 252.

- Ivanković, M., Bogdan, S., Božić, G., 2008: Varijabilnost visinskog rasta obične bukve (Fagus sylvatica L.) u testovima provenijencija u Hrvatskoj i Sloveniji, Šumarski list br. 11-12: 529-541.

- Kajba, D., 2003: Unutarpopulacijska i međupopulacijska varijabilnost obične bukve. U: Obična bukva (Fagus sylvatica L.) u Hrvatskoj, Matić, S. (ur.), Akademija šumarskih znanosti \& Hrvatske šume, Zagreb, 247-263.

- Kienitz, M., 1879: Über die Formen und Abarten heimischer Waldbäume. Forstl. Z.: 241-260. 
- Larsen, B. (1985): Beechprovenances in Denmark. „Symp. Verbesserung und Waldbau der Buche" in: Mitteilungen der Bundesforschungsanstalt für Forst und Holzwirtschaft, Hamburg, 150: 85-91.

- Liesebach, M., Degen, B., Scholz, F., 1999: Zur genetischen Anpassungsfähigkeit der Rotbuche (Fagus sylvatica L.). Berichte über Landwirtschaft, Münster, 77: 128-133.

- Muhs, H.J., 1985: International provenance trial of beech (Fagus sylvatica L.) from 1983/85. Mitteilungen der Bundesforschungsanstalt für Forst und Holztechnologie, 3. IUFRO Buchensymposium, Zvolen, 77-83.

- Pintarić, K., 2000: 30 godina istraživanja na arišu različitih provenijencija u Bosni. Šumarski list, 3-4: 143-156.

- Petkova K., Molle E., Huber G., Konnert M., Gaviria J. 2017: Spring and autumn phenology of Bulgarian and German provenances of Common beech (Fagus sylvatica L.) under similar climatic conditions, Silvae Genetica, 66, 24-32
- Pintarić, K., 2002: Šumsko-uzgojna svojstva i život važnijih vrsta šumskog drveća. Udruženje šumarskih inženjera i tehničara Federacije Bosne i Hercegovine, str. 111-116.

- Pukacki, P., 1990: Otpornošć na niskie temperatury. In: Buk zwyczajny - Fagus sylvatica L. S. Bialobok (ed.),. Warszawa Poznan, Panstwowe Wydawnictwo Naukowe, 185-192.

- Teissier Du Cros, E., Thiebaut, B., Duval, H., 1988: Variability in beech : budding, height growth and tree form. Annales des sciences forestières, INRA/EDP Sciences, 1988, 45 (4), pp.383398. ffhal-00882456f

- Urbani, N., 1914: Phenološke bilješke. Šumarski list br. 1, 38:16-20.

- Vidaković, M., Krstinić, A., 1985: Genetika i oplemenjivanje šumskog drveća. Sveučilište u Zagrebu, Šumarski fakultet, Udžbenici Sveučilišta u Zagrebu, 213-214.

- Von Wüehlisch, G., Krusche, D., Muhs, J. 1995: Variation in temperature sum requirement for flushing of beech provnances. Silvae Genet. 44: 343-346.

\section{SUMIMARY}

The study aims to compare the growth of common beech provenances, and to determine the beginning and end of the phenological stages of leafing in the international provenance test in Bosnia and Herzegovina.

In this research, we measured morphological traits and observed phenology on common beech plants in the international provenance test near Kakanj, Bosnia and Herzegowina. The test was established in 2006 with one-year-old and two-year-old seedlings. It includes eight provenances from Bosnia and Herzegovina, four from Germany, three from Serbia, two each from Croatia, Romania, and Switzerland, and one from Hungary (table 1).

In the spring of 2017, we measured the heights (in $\mathrm{cm}$ ) and root collar diameters (in mm) of plants and observed six phenological phases of leafing (figure 1): A - Sleeping buds; B - Buds swelled; C - Buds begin to open; D - Hairy leaves begin to appear; E - Leaves open, still fanlike; F - Leaves fully developed.

Analysis of variance showed statistically significant differences among provenances for morphological traits of height (table 3), and root collar diameter (table 6). Duncan test showed grouping of populations into seven groups for the trait of height (table 8), and eight groups for the trait of root collar diameter (table 10), but groups overlapped.

Multivariate analysis for height (Table 7) and root neck diameter (Table 9) revealed statistically significant differences only at the population level and not between trees within the population, nor at the population interaction level $x$ tree.

The average height for all provenances was $164.6 \mathrm{~cm}$ (table 2), and the average root collar diameter was $33.4 \mathrm{~mm}$ (table 5). The lowest average height $(104.2 \mathrm{~cm})$ and root collar diameter $(22.6 \mathrm{~mm})$ had provenance of Alba - Iulia from Romania (9664). The highest average height $(197.4 \mathrm{~cm})$ and root collar diameter $(40.1 \mathrm{~mm})$ had provenance Dilj Čaglinski from Croatia (9624).

We identified differences between provenances regarding the occurrence of phenological stages of leafing (table 11), as well as regarding the duration of phenological phases (table 10). Phase B occurred the earliest on 31.3. in provenances Grmeč Jasenica and Dinara from Bosnia and Herzegovina and Cer from Serbia. Phase B occurred the latest on 8.5 in provenances Herzogenbuchsee from Switzerland and NS Hasbruch from Germany. Phenophase F appeared the earliest on 1.5. in provenance Valkony from Hungary. Analysis of variance showed statistically significant differences among provenances for the length of phenological stages (table 12).

Further measurements of morphological traits need to be made to determine the tendencies of growth of particular provenances in subsequent stages of development.

It is also necessary to observe the phenological stages of leafing. It will help to evaluate the effects of the genetic constitution and annual climate on phenological trends. The results of this study will be used to choose the best provenances in terms of productivity and resistance to late spring frosts.

KEY WORDS: leafing phenological stages, height, root collar diameter, common beech, provenance test 